\title{
Frugal or Fair? The Unfulfilled Promises of Frugal Innovation Mario Pansera
}

\author{
"People need new tools to work with rather than new") \\ tools that work for them.
}

Ivan Illich (1926-2002)

In Tools for Conviviality (1973)

\begin{abstract}
Frugal innovation has become a popular buzzword among management and business scholars. However, despite its popularity, I argue that the frugal innovation literature, in its present form, is problematic for at least two reasons. First, the frugal innovation literature assumes that scarcity is a normal condition of the "Global South". In this article, I show that this assumption neglects the fact that scarcity can be socially constructed to deny certain social sectors the access to resources essential for their flourishing. Second, despite all the good intentions underpinning the idea of "alleviating poverty", frugal innovation studies rarely challenge, or even discuss, the causes of destitution and social exclusion. Innovation, as well as technology, is overwhelmingly framed in an agnostic and neutral way that sidelines the socio-economic complexity of the exclusion mechanisms that cause poverty and underdevelopment. By ignoring this, the frugal innovation literature risks limiting the understanding of the problems it seeks to solve and, most importantly, it risks limiting its impact. Most frugal innovation literature, in other words, seems to elude the fact that, rather than being a mere lack of resources or technology, poverty is a matter of social justice. In order to be empowering, technology has to be value-based, normative framed, socially controlled, and democratically debated. In this article, I propose that we should use these principles to develop a new wave of frugal innovation literature and practice.
\end{abstract}

\section{Introduction}

Frugal innovation has become a popular buzzword in the last two decades (Pisoni et al., 2018; Tiwari et al., 2017). The notion went under the radar of an increasing variety of academics and practitioners that span from organizations studies and management scholars to non-governmental organizations and multinational corporations (Hossain, 2016). The basic idea is that innovation can and does emerge even where and when financial, material, and human resources are scarce (Pansera, 2013). This concept is extremely relevant for those interested in improving the living conditions of the poor of the world, who confront every day with resource constraints. If innovation is possible everywhere, at least in its frugal, low-technology and low-cost forms, why would we not use it to alleviate poverty?
The concept itself is not new. The idea of developing "good-enough" solutions for the poor dates back (at least) to the appropriate technology movement initiated by E. F. Schumacher in the 1970s (Kaplinsky, 2011; Schumacher, 1973) and, in a quite different formulation, in the work of Ivan Illich (1973). What it is new is the kind of authors and audience that now debate the topic, including business, innovation, and organizational scholars (Pansera \& Owen, 2017). This new trend has very much monopolized the debate around two basic assumptions:

1. Poverty is caused by resource scarcity; thus, frugal innovation might help solve poverty.

2. Frugal innovation offers a "triple bottom line" approach able to create social impact, environmental benefits, and business opportunities. 


\section{Frugal or Fair? The Unfulfilled Promises of Frugal Innovation}

\section{Mario Pansera}

In this article, I will argue that those assumptions are problematic - and thus so is most of the frugal innovation literature in its present form - for two main reasons. First, despite all the good intentions behind the idea of alleviating poverty, frugal innovation rarely challenges, or even discusses, the causes of poverty and social exclusion. Resource scarcity in the "Global South" (Box 1) is a complex phenomenon that is not necessarily linked to the lack of material or financial resources. On the contrary, natural and human resources are in many cases abundant but their access is often limited or totally denied to certain social groups. Second, the frugal innovation literature seems to ignore the insights and evidence coming from other fields, such as science and technology studies, responsible research and innovation, and post-development studies. The central argument of these contributions is that technological innovation is neither necessary nor sufficient to reverse the causes of poverty and exclusion. In certain circumstances, innovation, even if frugal, can reinforce unequal power relationships by favouring those who already enjoy privileged positions in the community (Pansera \& Owen, 2018). In order to be empowering, technology has to be value-based, rooted in solid normative framings and socially controlled (Stirling, 2008).

This article is structured as follows. In the next section, I discuss the notion of scarcity as a social construct and its implications for the idea of frugal innovation. In the third section, I describe the apolitical rhetoric that characterizes, I argue, most of the literature on frugal innovation. Finally, I conclude by inviting academics and practitioners to re-introduce political questions in the study of innovation for development.

\section{The Idea of Scarcity and Its Limits}

Necessity is the mother of invention. This popular phrase suggests that the necessity to address compelling needs sharpens ingenuity and encourages innovative thinking. Recent literature focused on business and management has approached the topic by introducing such concepts as frugal innovation but also resourceconstrained innovation, bricolage, or jugaad (Horn \& Brem, 2013). The main argument here is that scarcity of (material, financial, human, or organizational) resources can stimulate the search for innovative solutions that are cost-effective, more efficient (e.g., reduce the use of water, energy, material, labour), often more socially acceptable, and even greener. For these reasons, proponents of frugal innovation suggest that frugality can have great implications for the global com-

\section{Box 1. The Global South}

The term "Global South" indicates what used to be called the "Third World" (i.e., Africa, Latin America, and the developing countries in Asia), "developing countries", "less developed countries", or "less developed regions". More than an economic classification, the term Global South refers to a specific geo-political order, an arrangement of power relationships that dominate the relations between the former dominant colonial empires and the dominated colonies. As Dados and Connell (2012) eloquently say, the term refers to these countries' "interconnected histories of colonialism, neoimperialism, and differential economic and social change through which large inequalities in living standards, life expectancy, and access to resources are maintained".

petitiveness of the middle-low income countries (Zeschky et al., 2011; Zeschky et al., 2014) and represents an alternative pathway for their sustainable development (Rosca et al., 2017).

The idea of frugal innovation is also central in the socalled "bottom of the pyramid" literature (Kolk et al., 2013). The notion of the bottom of the pyramid was famously introduced by Prahalad in 2005 in his book The Fortune at the Bottom of the Pyramid: Eradicating Poverty through Profits (Prahalad, 2010). The main argument posited by Prahalad's work is that the poor are unserved consumers who represent an immense unexploited market. Those at the bottom of the pyramid, he argues, are currently excluded from mass consumption because of their very limited purchasing power. By appropriately targeting the poor, the private sector would have access to new and unsaturated markets and the poor, in turn, would gain access to consumer goods that are currently inaccessible because they are too expensive, raising their standards of living. In a nutshell: doing more with less and for more people (Prahalad, 2010, 2012; Prahalad \& Mashelkar, 2010). Central to the bottom-of-the-pyramid concept is the idea that poverty can be addressed by increasing consumption of material goods. The strategy, then, is to produce affordable - frugal - products and services with the objective of raising the consumption rate of the poor. According to these scholars, those institutions that are best placed to implement such a strategy are multinational corporations (Kanter, 2008; Rosenbloom 


\section{Frugal or Fair? The Unfulfilled Promises of Frugal Innovation}

\section{Mario Pansera}

\& Althaus, 2007). The underlying philosophy of the bottom-of-the-pyramid approach is that the quest for profit can simultaneously generate economic growth and deliver social value (that in this case equals material consumption): making money by doing good (Agnihotri, 2013; Bardy et al., 2012; Chakravarti, 2006; Faulconbridge, 2013; Seelos \& Mair, 2007).

Although frugal innovation and its companion buzzwords (e.g., jugaad, resource-constrained innovation, bottom-of-the-pyramid innovation) remain essentially flexible notions, their definitions and meanings are continuously contested and reframed (see also Soni \& Krishnan, 2014 and Arora \& Romijn, 2011), they share the fundamental assumption that poverty is caused by a lack of resources. However, instead of discussing how to escape scarcity, most frugal innovation literature is merely focused on the study of those capabilities that are presumably needed to innovate in resource-scarce contexts. For instance, Srinivas and Sutz (2008) argue that, in the academic literature, there has been a misguided quest for uniformity of the conditions in which innovation occurs (i.e., abundance of resources, efficient institutions, developed markets, etc.). This has in turn sidelined the study of those capabilities needed to innovate in conditions of scarcity, conditions that characterize large sections of the so-called developing world. In this view, scarcity is a given variable, an inescapable condition that characterizes the Global South. There are good reasons to think that this assumption is groundless.

First, let me distinguish between what Mehta (2005) calls "lived/experienced" scarcity (i.e., shortages of food, water, fodder, etc. that local people experience cyclically due to biophysical conditions) and "constructed" scarcity (i.e., shortages artificially manufactured through socio-political processes to suit the interests of powerful players). There is no doubt that certain regions of the globe present serious limits of critical resources such as water, arable land, or livestock. In these situations, human societies react by developing a huge variety of strategies to cope with cyclical scarcity. The work of Elinor Ostrom demonstrates that human societies are able to create complex systems for the management of common resource pools that are based on collaboration, solidarity, and equality (Ostrom, 1990, 2010). In those contexts, scarcity as such is not perceived as a constraint because the wants of the community are shaped on the availability of resources, that, in turn, are allocated through social processes that favour (at least in principle) equal allocation to guarantee the resilience of the system. The same mechanisms doc- umented by Ostrom are also very well known by anthropologists that have provided overwhelming evidence that in non-market societies people satisfy their wants through a different logic that includes reciprocity, redistribution, and exchange (Polanyi, 2001; Sahlins, 1992). This does not mean that pre-industrial societies are fairer or inherently egalitarian. It is important not to romanticize traditional societies that, in many cases, have been proven to be extremely oppressive and unjust. The important lesson that comes from the "ethnography of the commons" is that collaborative behaviour can be a crucial advantage under conditions of resource scarcity.

Constructed scarcity, on the other hand, is not directly linked to an absolute lack of resources or biophysical limits, but it is socially constructed. Yapa (1996), for instance, shows that, in many contexts, scarcity is not experienced by society at large, but instead by specific social sectors and is a "socially specific condition". Scarcity, in this view, is the result of exclusion and unequal gender, social, and power relations that legitimize asymmetric access to and control over finite resources (Mehta, 2010). Land dispossession, privatization of commons, and even colossal state-driven development projects such as dams, mines, and power plants all can contribute to constructed scarcity that eventually leads to a mass of new prolitarianized urban poor (Baka, 2013; Escobar, 2012). This explains why rich regions in the Indian Subcontinent, Africa, Asia or the Americas are still characterized by huge pockets of poverty despite their enormous natural resources stocks and their ancient and complex agricultural know-how and indigenous knowledge. This also explains why relative poverty in the Global North is increasing whereas access to social welfare and public goods are decreasing despite unprecedented levels of wealth accumulation. The assumption of scarcity ubiquity that underpins most of the frugal innovation literature neglects the politics of resource allocation and the ways scarcity is politicized, especially to suit the interests of powerful groups. By focusing on the skills that are needed to innovate in resource-constrained contexts, the frugal innovation literature has refused to seriously engage with the social and political factors that force certain groups to innovate under conditions of scarcity.

\section{The Apolitical Rhetoric of Frugality}

Above, I argued that the frugal innovation literature is generally based on incorrect assumptions about the ubiquity and the origin of scarcity. This situation arose, 


\section{Frugal or Fair? The Unfulfilled Promises of Frugal Innovation}

\section{Mario Pansera}

in my view, because the frugal innovation literature emerged in a pro-business intellectual environment that unconsciously - but in some cases even overtly frames innovation, science, and technology in an apolitical way. My recent studies on the discourses of innovation in the Indian Subcontinent suggest that this is also true in the case of similar notions that usually surround frugal innovation such as bottom-of-the-pyramid innovation, inclusive innovation, or inclusive growth (Pansera \& Owen, 2017, 2018). I found that narratives of frugality and inclusive innovation usually promulgates a depoliticized rhetoric of inclusion and participation that neglects the existence of unequal global and local power relations and norms that are known to shape the processes of socio-technical change and innovation, while unreflexively perpetuating capitalist hegemony at a global scale. Arora and Romijn (2011) describe this process as follows:

“...the Bottom of the Pyramid literature is rap-
idly inching toward a new corpus of apolitical
management studies for managing the (adverse)
incorporation of the poor into world markets and
further neoliberalization of extremely indigent
areas of the planet. Such an apolitical understand-
ing of complex social dynamics, by masking extant
privilege and its consolidation will only serve to re-
produce existing inequalities at the local level and
further entrench the dominance of national and
global capitalist formations."

We might replace "bottom of the pyramid literature" with frugal innovation literature" and the main message of the quotation still would be valid. In the frugal innovation literature, innovation, as well as technology, is overwhelmingly framed in an agnostic and neutral way that sidelines the socio-economic complexity of the exclusion mechanisms that underpin poverty and underdevelopment. There is an extended literature that shows how technology can be socially constructed to exclude or favour certain social groups (Leach et al., 2010). By ignoring this, the frugal innovation literature risks limiting the understanding of the problem it seeks to solve and, most importantly, it risks limiting its impact. Most frugal innovation literature, in other words, seems to elude the fact that rather than being a mere lack of resources or technology, poverty is a matter of social justice (Smith et al., 2014).

In my view, a new wave of frugal innovation studies might enormously benefit from disciplines that emphasize the role of society, power dynamics, and culture in the emergence of innovation. I refer here to science and technology studies (Winner, 1980), development and post-development studies (Escobar, 2012), and those authors that attempt to re-politicize the links between poverty, inequality, and innovation (Ferguson, 1990; Swyngedouw, 2015). In particular, I argue that authors interested in frugal innovation could benefit from the insights coming from the grassroots innovation literature. According to Smith, Fressoli, and Thomas (2014) grassroots innovation discourse rests on three key dimensions. First, like frugal innovation, it is locally-specific yet widely-applicable: grassroots ingenuity stimulates innovation that can be applied locally as project-based solutions and, potentially, in a number of other contexts that share common features such as material and human resource scarcity (lived/experienced or constructed). Second, grassroots innovation movements encourage the emergence of socio-technical practices within different value systems than, for example, those associated with profit-driven innovation within a market economy paradigm. Third, it stimulates a debate about social reform, transformation, and structural change in light of extant economic and political structures. Smith and colleagues (2012) have documented the activities of several formal and informal networks of grassroots innovators in the Global South. Smith, Fressoli, and Thomas (2014) identify at least three major grassroots groups: the people's science movement and the Honey Bee Network (www.sristi.org/hbnew/) in India and the technologies for social inclusion movement in Latin America. These movements share the idea that innovation, science, and technology are a part of a participatory process of development where citizens themselves assume a central role. Rather than passive recipients of technology transfer, citizens are knowledgeable and actively involved in both upstream technology choice and design, and downstream deliberations around technology delivery and regulation (Leach et al., 2008). These movements deliberately chose to run a slower race opposed to the fast and frenetic competition race preached by capitalist globalization. In the words of Leach, Sumner, and Waldman (2008):

\footnotetext{
"[The slower race] emphasises pathways to poverty reduction which, while recognising the importance of science and technology, are specific to local contexts; recognise that technological fixes are not enough and that social, cultural and institutional dimensions are key; create hybrids between local and external knowledge for appropriate solutions, and go the extra mile to make already-existing technologies more readily available to those who are poor and marginalised. In
} 


\section{Frugal or Fair? The Unfulfilled Promises of Frugal Innovation}

\section{Mario Pansera}

this view, science and technology are a part of a participatory process of development where citizens themselves take centre stage. Rather than passive beneficiaries of trickle-down development or technology transfer, citizens are knowledgeable, active and centrally involved in both upstream technology choice and design, and downstream deliberations around technology delivery and regulation-perhaps challenging external perspectives. This, so the policy argument goes, makes for technologies more appropriate to the challenges of poverty reduction and social justice."

\section{Implications for Academics and Practitioners}

There are increasingly countervailing voices that call for a more complex understanding of the relation between poverty, technology, power, and resource allocation. The arguments those voices bring to the debate about frugal innovation have important implications for academics and practitioners. As regards management academics, I argue that it is crucial for them to reconsider critically the way they have promoted frugal innovation. As I showed elsewhere (Pansera \& Owen, 2018), some management scholars have been too often complicit with the interests of multinational corporations and uncritically aligned with the neoliberal ideology that promotes the idea that poor need material goods rather than justice, equal opportunities, or democracy. Most of them uncritically embraced the idea that frugal technology can be simply transferred to the poor without any significant implication for their lifestyle, their traditional networks of subsistence, their cultural bonds and moral values, and their social relations. They also promulgated the idea that the "inclusion" of the poor into the volatile global market would benefit both the companies and the socially excluded. Despite two decades of research, the evidence of this mutual benefit remains elusive.

The unfulfilled promises of frugal innovation suggest that management scholars need to redirect their effort towards other goals. A possible direction, as illustrated by the examples in the previous section, is to (re)politicize the study of poverty, possibly in collaboration with colleagues from other disciplines such as anthropology, sociology, geography, science and technology studies, innovation studies, or development studies. This essentially means to focus on the politics of innovation that is always context, value, and cultural based (Stirling, 2008).

Rather than being neutrally described, frugal innovation examples should be critically analysed by making ques- tions such as: Who wins? Who loses? By what mechanisms of power? What futures, new relations, and new arrangements do frugal innovation enable/disable? What are the alternatives? As Flyvbjerg (2001) has shown, endless research topics can spring from these questions. Here I suggest a few such topics that, in my opinion, remain under-researched:

- It is fundamental to understand under which conditions frugal innovation is able reshape power or social arrangements. We know that technology does not simply have the "innocence of the tools" but it does embed values, modes of being, and power arrangements (Pansera \& Owen, 2017; Winner, 1980). What kind of frugal technology in a given context is able (or can contribute) to the reshaping of the social mechanisms that underpin poverty and exclusion?

- Given that innovation always originates from learning processes and knowledge creation, it is crucial to understand what socio-technical arrangements facilitate the inclusion of forms of knowledge (e.g., indigenous or community knowledge) that are often considered "less legitimate" (or even subordinate) by scientific institutions but that can feed a flow of frugal, contextbased, and appropriate innovations (Winter \& Boudreau, 2018).

- Innovation can create or increase inequality (Cozzens \& Kaplinsky, 2009; Schillo \& Robinson, 2017); therefore, it is important to understand how frugal innovation can enable more equal forms of participation in the economic life of a village, region, or nation.

- Finally, it would be interesting to explore how frugal innovation can contribute to the creation of post-capitalist economies (Parker et al., 2014) and the flourishing of non-monetized forms of economy (e.g., gift economies, social innovation, solidarity economies) vis-à-vis the expansion of market capitalism (Zanoni et al., 2017).

A more nuanced way of framing scarcity and frugality could also benefit the work of practitioners and businesses that are sincerely interested in addressing the problem of poverty in the Global South but also the rising inequality in the North. My suggestion is to explore different ways of creating value that are more inclusive, more transformative, and more democratic. This implies the inclusion and recognition of different forms of knowledge, as mentioned above, but it also requires a serious engagement to create equal relationships based on mutual recognition with a variety of 


\section{Frugal or Fair? The Unfulfilled Promises of Frugal Innovation}

\section{Mario Pansera}

stakeholders. A particular emphasis, in my opinion, should be given to those organizational models that use subordinate knowledge to develop technological solutions (especially in their "frugal" form) that challenge the power arrangements that create exclusion. Some examples are:

- Those organizations that challenge knowledge production systems based on "expert authority", such as the experiences of Kerala rural technologies (Pansera \& Owen, 2017) and the makers and open source communities (Smith et al., 2013).

- Those organizations that question hierarchy in the work places, such as social cooperatives and alternatives economies networks (Gibson-Graham, 2003; Parker et al., 2014).

- Those organizations that challenge the dynamic of top-down resource appropriation, such as community-business based on management of commons such as water, land, education, welfare, etc. (Kostakis et al., 2015; Sekulova et al., 2013).

\section{Conclusion}

In this article, I argued that, despite its increasing popularity, the frugal innovation literature is still problematic for two main reasons. First, it is mainly based on the idea that resource scarcity is just a natural condition in the Global South. I showed that this assumption is underpinned by an ideological posture that neglects the fact that scarcity can be socially constructed to deny certain social sectors the access to resources essential for their flourishing. Second, by framing underdevelopment as a technical or delivery problem, frugal innovation usually neglects that poverty is a socio-economic problem that requires a search for political solutions. The idea of innovation as a tool for addressing poverty, however, rests on highly contested ground.
The ways innovation is framed in the field of development implies a huge diversity of world views, values, motivations, interests, and political positions. Innovation is not an agnostic apolitical process but is rather, in the words of Sterling (2008), "a vector... increasingly recognized to be open to individual creativity, collective ingenuity, economic priorities, cultural values, institutional interests, stakeholder negotiation, and the exercise of power." The frugal innovation literature has barely engaged with the complex politics of resource allocation in the Global South. Furthermore, apart from scattered anecdotic evidence, frugal innovation has not delivered what it has promised. In order to better understand the role of innovation in the context of development, I argue, frugal innovation scholars have to re-politicize its study. They have to consciously and purposively engage with, and interrogate, the politics of poverty and scarcity.

\section{About the Authors}

Mario Pansera is a Research Fellow at the University of Bristol in the United Kingdom. He gained a $\mathrm{PhD}$ in Management from the University of Exeter Business School in the United Kingdom. His dissertation focused on the discourses of innovation and development with a particular interest for the Global South. He joined the University of Bristol after completing a Marie Skłodowska-Curie Post-Doctoral fellowship at the Academy of Business in Society in Brussels. His primary research interests are responsible research and innovation, sustainable and ecological transition, and the critique of the development discourse and growth. He is also particularly interested in the dynamics of innovation in emerging economies, appropriate technologies, grassroots, and social innovations. 


\section{Frugal or Fair? The Unfulfilled Promises of Frugal Innovation}

\section{Mario Pansera}

\section{References}

Agnihotri, A. 2013. Doing Good and Doing Business at the Bottom of the Pyramid. Business Horizons, 56(5): 591-599.

https://doi.org/10.1080/0965254X.2014.970215

Arora, S., \& Romijn, H. 2011. The Empty Rhetoric of Poverty Reduction at the Base of the Pyramid. Organization, 19(4): 481-505.

https://doi.org/10.1177/1350508411414294

Baka, J. 2013. The Political Construction of Wasteland: Governmentality, Land Acquisition and Social Inequality in South India. Development and Change, 44(2): 409-428.

http://doi.wiley.com/10.1111/dech.12018

Bardy, R., Drew, S., \& Kennedy, T. F. 2012. Foreign Investment and Ethics: How to Contribute to Social Responsibility by Doing Business in Less-Developed Countries. Journal of Business Ethics, 106(3): 267-282.

https://doi.org/10.1007/s10551-011-0994-7

Chakravarti, D. 2006. Voices Unheard: The Psychology of Consumption in Poverty and Development. Journal of Consumer Psychology, 16(4): 363-376.

https://doi.org/10.1207/s15327663jcp1604_8

Cozzens, S., \& Kaplinsky, R. 2009. Innovation, Poverty and Inequality: Cause, Coincidence, or Co-Evolution? In B.-A. Lundvall (Ed.), Handbook of Innovation System and Developing Countries: 57-82. Cheltenham, UK: Edward Elgar.

Dados, N., \& Connell, R. 2012. The Global South. Contexts, 11(1): $12-13$.

https://doi.org/10.1177/1536504212436479

Escobar, A. 2012. Encountering Development: The Making and Unmaking of the Third World (2nd ed.). Princeton, NJ: Princeton University Press.

Faulconbridge, J. R. 2013. Situated Bottom of the Pyramid Markets and the Multinational Corporation. Marketing Theory, 13(3): 393-396. https://doi.org/10.1177/1470593113489192

Ferguson, J. 1990. The Anti-Politics Machine: "Development," Depoliticization, and Bureaucratic Power in Lesotho. Cambridge, UK: Cambridge University Press.

Flyvbjerg, B. 2001. Making Social Science Matter. Cambridge, UK: Cambridge University Press.

Gibson-Graham, J. K. 2003. Enabling Ethical Economies: Cooperativism and Class. Critical Sociology, 29(2): 123-161. https://doi.org/10.1163/156916303769155788

Horn, C., \& Brem, A. 2013. Strategic Directions on Innovation Management - A Conceptual Framework. Management Research Review, 36(10): 939-954. https://doi.org/10.1108/MRR-06-2012-0142

Hossain, M. 2016. Grassroots Innovation: A Systematic Review of Two Decades of Research. Journal of Cleaner Production, 137: 973-981. https://doi.org/10.1016/j.jclepro.2016.07.140

Illich, I. 1973. Tools for Conviviality. New York: Harper \& Row.

Kanter, R. M. 2008. Transforming Giants. Harvard Business Review, 86(1): 43-52, 136.
Kaplinsky, R. 2011. Schumacher Meets Schumpeter: Appropriate Technology Below the Radar. Research Policy, 40(2): 193-203. https://doi.org/10.1016/j.respol.2010.10.003

Kolk, A., Rivera-Santos, M., \& Rufin, C. 2013. Reviewing a Decade of Research on the "Base/Bottom of the Pyramid" (BOP) Concept. Business \& Society, 20(10): 2-40. https://doi.org/10.1177/0007650312474928

Kostakis, V., Niaros, V., \& Giotitsas, C. 2015. Production and Governance in Hackerspaces: A Manifestation of Commons-Based Peer Production in the Physical Realm? International Journal of Cultural Studies, 18(5): 555-573. https://doi.org/10.1177/1367877913519310

Leach, M., Scoones, I., \& Stirling, A. C. 2010. Dynamic Sustainabilities: Technology, Environment, Social Justice. London, New York: Routledge/Earthscan.

Leach, M., Sumner, A., \& Waldman, L. 2008. Discourses, Dynamics and Disquiet: Multiple Knowledges in Science, Society and Development. Journal of International Development, 20(6): 727-738. https://doi.org/10.1002/jid.1492

Mehta, L. (Ed.). 2010. The Limits to Scarcity. Contesting the Politics of Allocation. London: Earthscan.

Metha, L. 2005. The Politics and Poetics of Water: Naturalising Scarcity in Western India. New Delhi: Orient Longman.

Ostrom, E. 1990. Governing the Commons: The Evolution of Institutions for Collective Action. Cambridge, UK: Cambridge University Press.

Ostrom, E. 2010. Polycentric Systems for Coping with Collective Action and Global Environmental Change. Global Environmental Change, 20(4): 550-557. https://doi.org/10.1016/j.gloenvcha.2010.07.004

Pansera, M. 2013. Frugality, Grassroots and Inclusiveness: New Challenges for Mainstream Innovation Theories. African Journal of Science, Technology, Innovation and Development, 5(6): 469-478. https://doi.org/10.1080/20421338.2013.820445

Pansera, M., \& Owen, R. 2017. Innovation for De-Growth: A Case Study of Counter-Hegemonic Practices from Kerala, India. Journal of Cleaner Production, In press.

https://doi.org/10.1016/j.jclepro.2016.06.197

Pansera, M., \& Owen, R. 2018. Framing Inclusive Innovation within the Discourse of Development: Insights from Case Studies in India. Research Policy, 47(1): 23-34.

https://doi.org/10.1016/j.respol.2017.09.007

Parker, M., Cheney, G., Fournier, V., \& Land, C. (Eds.). 2014. The Routledge Companion to Alternative Organization. Oxford: Routledge.

Pisoni, A., Michelini, L., \& Martignoni, G. 2018. Frugal Approach to Innovation: State of the Art and Future Perspectives. Journal of Cleaner Production, 171(10): 107-126. https://doi.org/10.1016/j.jclepro.2017.09.248

Polanyi, K. 2001. The Great Transformation: The Political and Economic Origins of Our Time. Boston, MA: Beacon Press.

Prahalad, C. K. 2010. The Fortune at the Bottom of the Pyramid: Eradicating Poverty through Profits (2nd ed.). Upper Saddle River, NJ: Pearson Education. 


\section{Frugal or Fair? The Unfulfilled Promises of Frugal Innovation}

\section{Mario Pansera}

Prahalad, C. K. 2012. Bottom of the Pyramid as a Source of Breakthrough Innovations. Journal of Product Innovation Management, 29(1): 6-12.

https://doi.org/10.1111/j.1540-5885.2011.00874.x

Prahalad, C. K., \& Mashelkar, R. A. 2010. Innovation's Holy Grail. Harvard Business Review, 88(7/8): 132-141.

Rosca, E., Reedy, J., \& Bendul, J. C. 2017. Does Frugal Innovation Enable Sustainable Development? A Systematic Literature Review. The European Journal of Development Research, 30(1): 136-157. https://link.springer.com/article/10.1057/s41287-017-0106-3

Rosenbloom, A., \& Althaus, R. 2007. Reducing Global Poverty: Building the Business Case. International Journal of Interdisciplinary Social Sciences, 2(1): 417-423.

Sahlins, M. 1992. The Economics of Develop-Man in the Pacific. Anthropology and Aesthetics, 21: 12-25.

https://doi.org/10.1086/RESv21n1ms20166839

Schillo, R. S., \& Robinson, R. 2017. Inclusive Innovation in Developed Countries: The Who, What, Why, and How. Technology Innovation Management Review, 7(7): 34-46.

https://timreview.ca/article/1089

Schumacher, E. F. 1973. Small is Beautiful. New York: Harper \& Row.

Seelos, C., \& Mair, J. 2007. Profitable Business Models and Market Creation in the Context of Deep Poverty: A Strategic View. Academy of Management Perspectives, 21(4): 49-63. https://doi.org/10.5465/AMP.2007.27895339

Sekulova, F., Kallis, G., Rodríguez-Labajos, B., \& Schneider, F. 2013. Degrowth: From Theory to Practice. Journal of Cleaner Production, 38: $1-6$.

https://doi.org/10.1016/j.jclepro.2012.06.022

Smith, A., Arond, E., Fressoli, M., Thomas, H., \& Abrol, D. 2012. Supporting Grassroots Innovation: Facts and Figures. SciDev.Net, May 2, 2012. Accessed April 16, 2018:

http://www.scidev.net/global/enterprise/spotlight/supportinggrassroots-innovation.html

Smith, A., Fressoli, M., \& Thomas, H. 2014. Grassroots Innovation Movements: Challenges and Contributions. Journal of Cleaner Production, 63: 114-124.

https://doi.org/10.1016/j.jclepro.2012.12.025

Smith, A., Hielscher, S., Dickel, S., Soderberg, J., \& van Oost, E. 2013. Grassroots Digital Fabrication and Makerspaces: Reconfiguring, Relocating and Recalibrating Innovation? SPRU Science and Technology Policy Research Working Paper SWPS 2013-02. Brighton, UK: University of Sussex.

http://sro.sussex.ac.uk/49317/1/2013_02_SWPS_APS_SH_GDF_wo rking_paper.pdf

Soni, P., \& T. Krishnan, R. 2014. Frugal Innovation: Aligning Theory, Practice, and Public Policy. Journal of Indian Business Research, 6(1): 29-47.

https://doi.org/10.1108/JIBR-03-2013-0025
Srinivas, S., \& Sutz, J. 2008. Developing Countries and Innovation: Searching for a New Analytical Approach. Technology in Society, 30(2): 129-140.

https://doi.org/10.1016/j.techsoc.2007.12.003

Stirling, A. 2008. "Opening Up" and “Closing Down": Power, Participation, and Pluralism in the Social Appraisal of Technology. Science, Technology \& Human Values, 33(2): 262-294. https://doi.org/10.1177/0162243907311265

Swyngedouw, E. 2015. Depoliticization (“The Political”). In G. D'Alisa, F. Demaria, \& G. Kallis (Eds.), Degrowth: A Vocabulary for a New Era: 90-93. London: Routledge.

Tiwari, R., Fischer, L., \& Kalogerakis, K. 2016. Frugal Innovation in Scholarly and Social Discourse: An Assessment of Trends and Potential Societal Implications. Working Paper. Hamburg and Leipzig, Germany: Center for Frugal Innovation, Hamburg University of Technology, Fraunhofer Center for International Management and Knowledge Economy.

https://doi.org/10.15480/882.1288

Winner, L. 1980. Do Artifacts Have Politics? Daedalus, 109(1): 121-136. http://www.jstor.org/stable/20024652

Winter, J., \& Boudreau, J. 2018. Supporting Self-Determined Indigenous Innovations: Rethinking the Digital Divide in Canada. Technology Innovation Management Review, 8(2): 38-48. https://doi.org/10.22215/timreview/1138

Yapa, L. 1996. What Causes Poverty? A Postmodern View. Annals of the Association of American Geographers, 86(4): 707-728. https://doi.org/10.1111/j.1467-8306.1996.tb01773.x

Zanoni, P., Contu, A., Healy, S., \& Mir, R. 2017. Post-Capitalistic Politics in the Making: The Imaginary and Praxis of Alternative Economies. Organization, 24(5): 575-588.

https://doi.org/10.1177/1350508417713219

Zeschky, M., Widenmayer, B., \& Gassmann, O. 2011. Frugal Innovation in Emerging Markets. Research-Technology Management, 54(4): 38-45.

https://doi.org/10.5437/08956308X5404007

Zeschky, M., Winterhalter, S., \& Gassmann, O. 2014. From Cost to Frugal and Reverse Innovation: Mapping the Field and Implications for Global Competitiveness. Research-Technology Management, 57(4): 20-27.

https://doi.org/10.5437/08956308X5704235

Citation: Pansera, M. 2018. Frugal of Fair? The Unfulfilled Promises of Frugal Innovation. Technology (cc) BY Innovation Management Review, 8(4): 6-13.

http://doi.org/10.22215/timreview/1148

Keywords: frugal innovation, inclusive innovation, social justice, scarcity 


\section{Academic Affiliations and Funding Acknowledgements}

Canadà
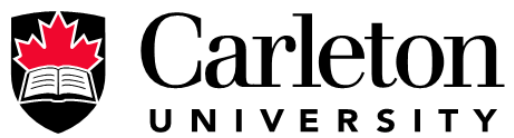

U N I V E R S I T Y

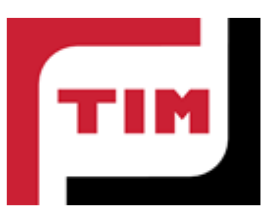

The Federal Economic Development Agency for Southern Ontario (FedDev Ontario; feddevontario.gc.ca) is part of the Innovation, Science and Economic Development portfolio and one of six regional development agencies, each of which helps to address key economic challenges by providing regionallytailored programs, services, knowledge and expertise.

- The TIM Review receives partial funding from FedDev Ontario's Investing in Regional Diversification initiative.

Technology Innovation Management (TIM; timprogram.ca) is an international master's level program at Carleton University in Ottawa, Canada. It leads to a Master of Applied Science (M.A.Sc.) degree, a Master of Engineering (M.Eng.) degree, or a Master of Entrepreneurship (M.Ent.) degree. The objective of this program is to train aspiring entrepreneurs on creating wealth at the early stages of company or opportunity lifecycles.

- The TIM Review is published in association with and receives partial funding from the TIM program. 